various methods of non-destructive testing. He gave results of tests on turbine disk forgings of austenitic steel which showed satisfactory agreement between radiography, ultrasonic examination and tensile tests. Mr. J. C. Rockley (A.I.D. Test House, Harefield) referred to the well-known radiographic inspection of stressed castings for aircraft and described three other useful applications : detection of internal corrosion in aircraft fuel tanks ; detection of faulty assembly of pitot pressure heads; detection of metallurgical defects in cartridge cases.

Dr. H. Harris (Babcock and Wilcox) stressed that the proper function of the radiographic examination of welded joints in pressure vessels is not so much to prove the acceptability of a particular weld as to correlate the weld with the test welds which are subject to mechanical tests. The greatest value of radiography is in developing welding processes rather than as a routine method of inspection.

Mr. H. S. Peiser (Hadfields, Ltd.) said that the fact that his firm is spending some $\mathfrak{1 5 , 0 0 0}$ on a new radiological laboratory is evidence of its belief in the value of industrial radiology. Mr. J. F. Hinsley (Edgar Allen and Co., Ltd.) spoke of the expansion of the radiological facilities of the firm which he represents. He referred to a very important radiographic examination of castings for the housing of electric traction motors, etc., and described the methods of repairing surface irregularities by welding. Mr. S. M. Reisser (Murex, Ltd.) stressed the importance and the difficulty of attaining uniformity in radiographic interpretation, and emphasized that full details of radiographic technique are essential for accurate interpretation.

An exhibition of industrial radiology arranged by Dr. D. H. Follett (Science Museum) was held through out the week. Some fifty exhibitors contributed to it, including the British Standards Institution, $\mathrm{Mr}$. F. I. G. Rawlins of the National Gallery (who demonstrated the radiography of oil paintings), and Dr. C. Moss of the British Museum (who showed archæological radiographs). There was also a variety of radiographs illustrating the use of radio isotopes, auto-radiography, flash radiography, and radiography with a 1.4-MeV. synchrotron. There were several photographs of radiographic equipment, including one of an X-ray laboratory in a railway coach, shown by Mr. Knights and Mr. Dearden of the Railway Executive, Midland Region. Apparatus was shown for the radiographic examination of pipe welds. One piece of apparatus exhibited enabled the level of mercury in a steel manometer tube (made necessary because the pressure is too great for glass to with stand) to be read by sending a beam of gamma-rays through the tube and detecting it with an ionization chamber and cathode-ray tube. The Armament Research Establishment of the Ministry of Supply exhibited a new type of sensitive penetrameter devised for use in the radiographic examination of welded joints. The same Establishment also exhibited a container for use in gamma-radiography, made from tungsten alloy to minimize the transmitted radiation. The operator can allow gamma-rays to emerge when required by an automatically released 'stopper', while remaining shielded from the radiation himself. It is suitable for sources up to 1 curie in strength, and the source is automatically returned to a safe position when the container is raised on completion of an exposure. One of the radiographs, taken with an exposure of one-millionth of a second, showed a bullet travelling through water.

\section{PLANT BREEDING IN GREAT BRITAIN}

WHE fourth annual conference of British plant breeders was held at the Scottish Plant Breeding Station, Corstorphine, Edinburgh, during August 3-4 and was attended by representatives of the John Innes Horticultural Institution, Bayfordbury; the Plant Breeding Institute, Cambridge; the Welsh Plant Breeding Station, Aberystwyth; the Plant Breeding Division, Ministry of Agriculture, Belfast; the National Vegetable Research Station, Wellesbourne; the Scottish Society for Research in Plant Breeding, Edinburgh; the Department of Agriculture for Scotland; and the Agricultural Research Council. At the conclusion of the conference, the invitation of Dr. C. D. Darlington, director of the John Innes Horticultural Institution, Bayfordbury, to hold the next conference at Bayfordbury in 1952 was accepted.

Sir John H. Milne Home welcomed the visitors on behalf of the board of directors of the Scottish Society for Research in Plant Breeding, and Sir Patrick Laird on behalf of the Department of Agriculture for Scotland. Mr. William Robb, director of research of the Scottish Society for Research in Plant Breeding, opened the proceedings by giving an account of the origin and organization of the Society, and the first morning of the conference was devoted to giving in turn an outline of the work of the various departments-cereal breeding by Mr. Robb, herbage breeding by Dr. J. W. Gregor, potato breeding by Dr. William Black, potato virus diseases investigations by Dr. G. Cockerham, and swede and sugar beet breeding by Dr. V. McM. Davey. The afternoon of August 3 and the morning and afternoon of August 4 were divided into five sessions, in which the party visited in turn the experimental plots of these departments, spending the morning of August 4 at the Potato Breeding Sub-Station at Boghall.

Cereals and Beans. In the breeding work with oats, the pedigree method of breeding has been mainly followed, but the 'bulk' method is now being tried. The main problems are to breed by hybridization and selection oats which are : productive, disease-resistant varieties highly resistant to lodging and having good quality milling grain which possesses resistance to germination at harvest time; hardy, early-ripening types for upland areas; and varieties showing a higher degree of tolerance of alkaline soil conditions than most standard varieties at present in cultivation.

A large number of unfixed hybrids were seen in plots in various stages of development, ranging from the first to the sixth generation. Attention was directed to various selections to illustrate the progress made in breeding for shorter straw and resistance to lodging, early-ripening types for upland areas, selections resistant to sprouting in the ear, and a selection adapted to alkaline soil.

Interest was shown in a number of transgressive segregates which illustrated wide genetical differences in length of straw and type of ear. The methods followed in testing the Society's new varieties at the Station, and at other centres in various parts of the country in co-operation with the three agricultural colleges in Scotland, were referred to, and the systerm followed in putting the Society's new varieties into commerce was outlined.

Mr. D. Cameron and Mr. H. D. Garvin demonstrated the work being done at the Station with barley and 
beans, and described that on the production of polyploid oats by means of colchicine and acenaphthene. An Avena sativa having a duplicated set of chromosomes obtained by colchicine treatment of the seed, and a duplicated Avena strigosa obtained by the immersion of the coleoptile in colchicine solution were shown. Crosses between these two duplicated types have given a number of grains, presumed to be the amphidiploid.

A sterile hybrid between $A$. barbata and $A$. strigosa was shown, from which some twenty seeds have been obtained this year following acenaphthene treatment in 1949, and the material will be examined cytologically.

With barley, a problem is to breed a malting barley with a low dormancy and suitable for combine harvesting. Attention was directed to a few hybrids in the $F_{3}$ generation which had been selected for low dormancy at harvest time, from crosses between Scots Common barley types.

In field beans the object has been to produce earlyripening upstanding varieties with a high podding capacity and medium-sized round seeds suitable for machine sowing. Plants selected from an $F_{2}$ or from an open-pollinated mixed population were inbred for a number of generations by selfing them inside cotton bags to reduce variation, before multiplying the inbred line in spatial isolation to build up stocks sufficiently large for inelusion in field trials.

The Station equipment for threshing, cleaning, grading and husking oats was demonstrated to those interested in that aspect of the work.

Herbage. During the morning of August 3, Dr. J. W. Gregor discussed the relative merits of the bred strain and the regional race, and suggested that the usefulness of the regional race as a direct source of commercial seed should be given greater consideration.

In the afternoon, Dr. Gregor, Dr. P. J. Watson and Dr. F. Earnshaw enumerated some of the problems being investigated, and demonstrated some of the growing material. The investigations which were discussed are largely concerned with the major problem of utilizing hill vegetation efficiently. It was pointed out that where stock numbers are determined by the amount of winter food available, an increase in summer herbage production alone would be wasteful, and for this reason it was suggested that intensive cultivation of grass at the lowest elevation might meet the requirements of breeding animals better than extensive re-seeding of upland grazing. The problem, therefore, is primarily one of providing a rich supplementary feed for breeding cattle during the time when rough grazings remain unproductive; in other words, raising the level of nutrition by the complementary use of 'wild' and protein-rich cultivated herbage. What is wanted is a sown sward or swards able to provide protein-rich complementary grazing from mid-April until the end of May, and again in September and October, as well as silage or hay crops during the summer months. It was also mentioned that, given appropriate treatment, interesting changes in the vegetation can be effected and certrin 'wild' plant communities can be used as protein-rich complementary grazing during the summer months.

Dr. Watson and Dr. Earnshaw dealt with some of the genecological investigations now in progress. This work, though primarily concerned with ecotypic differentiation and with the nature of the ecotype unit itself, has nevertheless a direct bearing upon the major problem of hill-land utilization. An endeavour is being made to study intensively the distribution of ecotypic variation along environmental gradients; and, in particular, attention is being paid to the spatial structure of intraspecific populations, and to the separation of ecotypic responses to altitudinal, edaphic and phytosocial gradients.

Potatoes. The potato-breeding work was described by Dr. Black, who explained that it is largely con. cerned with problems of disease resistance and with combining the different resistance qualities with the economic characters of commercial varieties. Natural resistance to each of the causal organisms of the more important diseases, blight, mosaics, leaf-roll, eelworm, scab and dry-rot, is to be found among the members of the potato family, and breeding experiments are designed to utilize the resistance factors as far as possible.

The problem of blight resistance was discussed in some detail, and methods of testing for resistance were demonstrated. In this work, seven different strains of the pathogen were employed for testing progenies derived from two main sources, namely, hybrids bred from $S$. demissum and $S$. tuberosum, and hybrids bred from $S$. Rybinii, $S$. demissum and $S$. tuberosum. Analysis of this material has shown that the blight resistance of $S$. demissum is controlled by at least four major independent genes which are inherited in simple Mendelian fashion.

The progress made in combining these genes with factors for resistance to other diseases was demonstrated in the field, where approximately a thousand selected seedlings have been grown in trial- and multiplication-plots for comparison as potential economic types.

Dr. J. C. Haigh demonstrated a number of species hybrids bred from $S$. demissum, $S$. simplicifolium, $S$. acaule and $S$. tuberosum, and explained their bearing on problems related to virus $Y$ resistance and frost resistance. He also demonstrated the experiments laid out to study the effect of species and varieties on the soil population of the potato root eelworm.

Potato Virus Diseases Investigations. The subject of resistance to potato viruses was briefly reviewed by Dr. Cockerham, who dealt mainly with the genetic and breeding aspects of various forms of resistance to the $A, X, Y$ and leaf-roll viruses. The methods of test used in recognizing and evaluating resistance characteristics were demonstrated, and attention was directed to a number of seedling varieties in which resistance to blight and virus diseases has been successfully combined. Current investigations being carried out by Miss T. M. R. McGhee and Mr. A. W. Macarthur on virus strains in relation to problems of resistance were explained in a demonstration of field-grown material infected with a series of strains of virus $X$.

Swedes and Sugar Beet. In discussing the breeding work with swedes (Brassica Napus v. Napobrassica), Dr. Davey described investigations which have been conducted since 1922 to test the possibilities of new breeding methods, and to attempt to obtain improved strains. Because the swede is potentially self-fertile, and seed propagated by the established trade method appears to be derived from both self- and crosspollinations, a technique for the seeding of single plants in pollen-proof bags has been adopted. This technique was demonstrated.

At first, pedigree lines were established starting with plants selected from commercial crops, and some lines have been carried on for fourteen genera- 
tions. Yield-trial results during the first twelve years indicated that about a third of the lines selected were worthless, while the remainder were not significantly better or worse than samples of their parent varieties. Improvement in uniformity was obtained, and it was concluded that the method might have some use in re-selecting contaminated stocks. Intervarietal crosses were made between the various swede types, and lines were selected which were also propagated by selfing. It was considered that these lines tended to become too uniform in their genetic constitution, so that after four generations it was difficult to effect any improvement in type or in performance. The intensity of inbreeding is now being lessened by intercrossing related phenotypes and by propagating one or more of the early generations as groups of mother plants in isolation. Selection for clubroot resistance is also being carried out on young plants grown in boxes of infected soil.

Investigations with sugar beet have been in progress for only three seasons. The yield of this crop in Scotland might be increased by sowing a few weeks before mid-April ; but bolting would then become a serious consideration. Non-bolting sugar beet material under course of development at the Cambridge Plant Breeding Institute is being tested, and further selection and propagation is being carried out in collaboration with that Institute. A trial which included bolting and non-bolting material was demonstrated by Dr. Davey and Mr. F. J. W. England.

\section{FIFTH INTERNATIONAL ANATOMICAL CONGRESS, 1950}

T HE Second World War was responsible for the cancellation of the Fifth International Anatomical Congress, which had been arranged to take place in Great Britain in 1940, and not until this year was it found possible to hold it. The previous Congress was in 1936 in Milan, so that another intermational meet ing was much overdue; and thus the Fifth Congress was held in Oxford during July 25-28, under the auspices of the Anatomical Society of Great Britain and Northern Ireland, with Prof. W. E. Le Gros Clark as president.

Altogether, thirty-six countries were represented at the Congress, but, with the exception of Jugoslavia, which sent three members, there was no representation of any of the Eastern European countries. Even so, the 535 members who eventually came constituted a record attendance. A Government reception was held in Christ Church prior to the opening session, and the members were welcomed on behalf of the Government by Viscount Addison, who before leaving academic life was himself a professor of anatomy. In his presidential address the next day, Prof. Le Gros Clark reviewed current trends in the study of anatomy, and, among other things, emphasized the thinness of the largely artificial barrier between anatomy and physiology; his speech has been published in the British Medical Journal (ii, 233 ; 1950). At the University Convocation which followed the opening plenary session, honorary degrees were conferred on Lord Addison, Prof. G. W. Corner (Baltimore), Prof. M. W. Woerdeman (Amsterdam) and Dr. L. S. B. Leakey (Nairobi).

The subject-matter of the scientific sessions reflected the wide range of interests of modern anatomists, and emphasized the fundamental nature of the study of anatomy in relation to other biological subjects. Indeed, so varied was the content of the two hundred or so communications that it is difficult to make any useful summary ; no official proceedings of the Congress are to be published. An attempt was made at rough classification into several groups: general anatomy, physical anthropology, neurology, histology, embryology and morphogenesis, and endocrinology and, so far as possible, papers with related subjectmatter were grouped together. This did not, however, prevent some strange juxtapositions. Thus, a paper on the mechanism of the interphalangeal joints in man was followed by one on the structure of the integument of the Anura; and a radiographic study of the mechanism of deglutition was succeeded by some remarks on the weak points of the lumbar region in Brazilian Indians.

In the section on neurology, which contained the greatest number of communications, there were two main groups, the first on the central nervous system, and the second on the peripheral nervous system and neurohistology. In addition, the greater part of two sessions concerned the peripheral parts of the autonomic system. The section on physical anthropology produced a spirited controversy regarding the origin and relationships of the Australopithecinæ, the observational evidence finding itself in conflict with the results of the more narrowly statistical approach. Among the other papers in this section were two dealing with the results so far obtained by the British-Kenya Miocene expedition. Under the heading of histology came several papers dealing with the application of phase-contrast microscopy to anatomical problems, and one whole session was devoted to papers dealing with bone. A number of new techniques were discussed, among them the use of microradiography and autoradiography. The section on embryology and morphogenesis included papers on experimental embryology and embryonic physiology as well as more purely descriptive papers. Lastly, in the endocrinology section, the main topics were the blood supply and functions of the pituitary and recent experimental work on the suprarenal cortex.

There were more than ninety demonstrations, involving some four hundred microscopes, and these, too, were roughly grouped together under headings. Here again, neurology was the heading under which came the greatest number of entries. Several films were shown, dealing with such diverse subjects as the tissue culture of osteoclasts and the recovery of skilled movements in monkeys after lesions in the motor cortex. An ad hoc discussion took place on the use of films in the teaching of normal anatomy, and in view of the difficulty, stressed by some Continental speakers, of obtaining material for dissection, it appears certain that there is scope for more and better teaching-films. The Congress resolved to form an international committee to approach the various and diverse sources known to be in possession of such films with the view to the formation of an international catalogue of available teaching material, and possibly the formation of a lending library.

It was also agreed to set up another committee, composed of delegates from the various national anatomical societies, to consider the difficult subject of modifying the present policy of laisser-faire with regard to anatomical terminology. The situation now is almost one of tot homines, quot sententice, since almost every nation has its own variant, usually, but 